\title{
A Reflection on the Sense of Understanding
}

\author{
Fang WANG \\ Foreign Languages Teaching and Research Dept,Luoyang Normal University, \\ Luoyang, China \\ 2456745@163.com
}

Keywords: Heidegger, Sense of understanding, Interpretation, Forestructure of understanding.

\begin{abstract}
In the light of Heidegger's analytics of Dasein, our thinking about the hidden structure behind the explicit understanding - interpretation which functions as a clue in bringing us close to that which has been covered up by it, will ultimately get us accessible to the most fundamental constitutive structure which existentially underlies all the explicit forms of different understandings in all people in spite of their age, sex, or nationality.
\end{abstract}

\section{Introduction:}

Let us begin with a story:

A child and a man were one day walking on the seashore when the child found a little shell and held it to his ear. Suddenly he heard sounds, - strange, low, melodious sounds, as if the shell were remembering and repeating to itself the murmurs of its ocean home. The child's face filled with wonder as he listened.... and he listened with delight to its mystery and music (EL, 1; italics added).

This is the first part of a story entitled "The Shell and the Book" in English Literature (EL) by William J. Long, relating an experience of understanding about a child. It is told in the form of an indirect report, foregrounding the question of the meaning of understanding and interpretation in terms of forestructure and as-structure.

\section{A Story of Understanding}

According to the second part of the same story, we know that what the story-teller obviously stresses is that the child, from the point of his instructor's view, is unable to enter timely into an appropriate condition of possibility to understand the meaning of the shell which is ontically present-at-hand. In the light of the synopsis that is revealed to us by the story-teller, we know that the shell as a being (that is, the shell has already been understood in some way by the child as what it is in advance before he can comport himself towards it as a shell) is arranged in such a way in which the shell just lies there directly and conspicuously in front of the child; while the child is presumed as one who is under the wrong conditions to respond to the openness of the shell in such a way in which his responding is consequently off the point and so waits for correction by his instructor. In the dialogical or conversational terms, the aforementioned shell and child clearly play the roles of the information-sender (stimuli-object) and the information-receiver (subject-response) respectively; yet according to the interpretation of the shell made by the "man" who turns out to be the child's instructor in that specific hermeneutic situation, this dialogical communication between the shell and the child falls flat thoroughly. The child's innocent and unpremeditated responses to the 
entity-shell like "wonder", "delight", "feeling strange", "seeing", and "hearing" are nothing but pointless, even no more than meaningless. That is, the child cannot properly make any sense of what the shell is as it is, for it looks as if the child who encounters (comes across) the shell is just like one who is affected by something whose being is, as it were, completely outside his understanding of being. To this in contrast, the "man" the child's instructor seems confidently able to sensibly interpret everything concerning the entity-shell to such an extent that his interpretation of the shell obviously manifests that he has already had the proper knowledge about the shell in store beforehand. So, in accordance with his forestructure of understanding which is now known as knowledge, the instructor can make a convincing or persuasive explanation about the shell. Here the different responses of the child and his instructor to the same object-shell give rise to a question: why do they differ in responding to the presenting of the same object-shell which is present-at-hand so greatly that their orientations of responding can be diametrically opposite to each other?

\section{Different Understandings between Long and Heidegger}

Before trying to answer this question, let us lay bare what is hidden under the appearance which covers up the phenomenon of the diversity of understandings between the child and his instructor in terms of their different ages. Our explication will proceed from two sides: Long and Heidegger.

In the story of "The Shell and the Book", the child, in Long's mind, must not have already possessed an understanding of being which can inform him about the shell what it is, because, in Long's narration, the child cannot intelligibly comport himself towards the shell as a kind of entity which has already been understood so and so. But the existential facticity of the child's behaving towards the shell is fundamentally against Long's intention, because the child's behaving towards the shell in such-and-such a manner is already the kind of understanding which is existentially based upon the primary understanding of being. According to Heidegger's existential-ontological analytics of Dasein (the human being), "we always conduct our activities in an understanding of Being. ... We do not even know the horizon in terms of which that meaning is to be grasped and fixed. But this average understanding of Being is still a Fact" (BT, 25; italics as in original). Here, we do not want to trace back far to the story of how the primitives gain the conditions of possibility of understanding of being (for even the primitives have their special understanding of being. See BT, 76), what we are trying to do is to disclose the hidden structure which lies behind the different interpretations between the child and his instructor in terms of understanding of being. In short, in the light of Heidegger's analytics of Dasein, our thinking about the hidden structure behind the explicit understanding - interpretation which functions as a clue in bringing us close to that which has been covered up by it, will ultimately get us accessible to the most fundamental constitutive structure which existentially underlies all the explicit forms of different understandings in all people in spite of their age, sex, or nationality.

Although the difference in answer between the child and his instructor comes presumably from their different age, yet age, in its narrow sense of time, is not the factor that in both proximity and priority determines the difference of response to the same object. Physiologically speaking, age signifies no more than a certain stretch of one's life. In the existential sense, however, age means what Heidegger thinks of temporality of time, therefore, it is a veil which covers its primordiality and hence prevents us from 
accessing its real meaning of being. Time is not so presumed as an absolutely objective schema outside our understanding of being and forces into our mind in order to participate in our cognition by giving it a time dimension; rather, time is a common measure posited as such upon our understanding of being - temporality, which is constituted upon the ground of our being alongside those entities characterized by changing (See Heidegger's explication of "Time" and "Temporality" in BT, Sections iii, iv and vi). In sum, the conception of time, according to Heidegger, is only the theoretical modification of temporality based upon experience with the changing entities present-at-hand within-the-world. Therefore, even the most "objective" thing such as time in traditional epistemology also results in our understanding of being, that is, temporality, so we cannot simply base our answer to that difference of response to the shell upon persons' ages, because, on the one hand, the conception of "age" cannot disclose its foundation of temporality; on the other hand it is too limited to be charged with the task of our questing for the meaning of the originality (primordiality) of ontical understandings.

In brief, what the different age covers up in the story of "The Shell and the Book" mentioned above is the forestructure of understanding which is ontically different from person to person though common to every human being ontologically. On the other hand, "the conception of time should be distinguished from the way in which it is ordinarily understood. ...we must make clear that this conception of time and, in general, the ordinary way of understanding it, have sprung from temporality" (BT, 39). For this purpose, "Time must be brought to light — and genuinely conceived — as the horizon for all understanding of Being and for any way of interpreting it. In order for us to discern this, time needs to be explicated primordially as the horizon for the understanding of Being, and in terms of temporality as the Being of Dasein, which understands Being” (ibid).

\section{The Forestructure of Understanding}

Every human being, in his destined span of life, has his own fore-having, fore-sight, and fore-conception, which consist in the formal forestructure of understanding, whose effects in the ontical understandings will never be eliminated or controlled thoroughly by "consciousness" to such an extent that one can cognize purely and objectively. That is to say, one cannot enter into his understanding of something without any bit of contamination of the forestructure of understanding, because "whenever something is interpreted as something, the interpretation will be founded essentially upon fore-having, fore-sight, and fore-conception. An interpretation is never a presuppositionless apprehending of something presented to us" (BT, 191-92). In the light of Heidegger's forestructure of understanding, Gadamer continues, "All correct interpretation must be on guard against arbitrary fancies and the limitations imposed by imperceptible habits of thought and direct its gaze 'on the things themselves'. It is clear that to let the object take over in this way is not a matter for the interpreter of a single decision ... A person who is trying to understand a text is always performing an act of projecting (of the forestructure of understanding; added). ... The working out of this fore-project, which is constantly revised in terms of what emerges as he penetrates into the meaning, is understanding what is there" " (TM, 236).

In sum, the different understandings of the child and his instructor in the previous story, though in appearance caused by the difference in age, is in essence due to the 
particular "mineness" of the forestructure of understanding, which makes the ontical understandings possible and different.

\section{Long's Blindness and Insight}

The second part of the story runs like this:

Then came the man, explaining that the child heard nothing strange; that the pearly curves of the shell simply caught a multitude of sounds too faintly for human ears, and filled the glimmering of hollows with the murmur of innumerable echoes. It was not a new world, but only the unnoticed harmony of the old that aroused the child's wonder (EL, 1; italics added).

Obviously, William J. Long sides with the instructor rather than the child. When the story comes to an end, he concludes:

Some such experience as this awaits us when we begin the study of literature, which has always two aspects, one of simple enjoyment and appreciation, the other of analysis and exact description (ibid).

The first-person plural pronouns "us", and "we", employed in the foregoing quotation indubitably refer to the child-like readers rather than experienced ones like the instructor who has probably been specially trained in the study of literature. It is clear that in Long's mind there are two types of readers, the inexperienced, untrained like the child and the experienced, properly informed and disciplined like the instructor. The child-like reader is marked by "simple enjoyment and appreciation", the instructor-like reader by "analysis and exact description". But child is child and instructor is instructor, they are different not only in terms of age but also in an unreflexive understanding of the world, that is, a given, externally determined practical situation; therefore, there should be no self-contradiction in one's encountering an entity, because such encountering is always founded upon its understanding of being which ultimately finds its way into one's being-in-the-world.

Upon what ground does Long regard the child's response to the shell as meaningless? The above story of understanding and Long's commentaries tell us that the ground is the instructor's standardized cognition of the shell based upon his generalized theoretical knowledge. It is clear that the child's response fails to reach this level of understanding. But the child's response to the shell is also the kind of understanding of being, or else he cannot intelligibly in such-and-such a manner comport himself towards the shell which is present-at-hand, although the intelligibility manifested in the child's comporting is suppressed by Long's agreement on the instructor's universalized understanding of the shell. In Long's mind, the child's response to the shell cannot be counted as qualified understanding, it is instinctive, amorphous in want of thematization and perfection. On the other hand, the instructor's interpretation of the shell is regarded as standard and universal, hence ideal by which all interpretations about shells must be measured.

\section{Conclusion}

Yet, if we follow Long's advice closely by taking over the instructor's reading of the shell we will lose the child's way of responding to the shell, which is full of somatic effects and states of mind. If this kind of bodily response is lost, then the meaning of the shell will be deprived of its exquisite human lustre. What is worse, only to let the type of the instructor's reading keep the weather in seeing and hearing, our access to the shell 
will be free-floating, accidental, and rootless, because the subject-object split approach would mean withdrawing the ground upon which our derivative ontical understandings are constituted, and this ground is our existential state of being-in-the-world which is co-original with our primary understanding of being of entities within-in-the-world.

\section{References}

[1] Heidegger, Martin. Being and Time. John Macquarrie \& Edward Robinson (trans.) China Social Sciences Publishing House Chengchengh Books Ltd., 1999.

[2] Hirsch, E. D. "A Defense of his version of hermeneutics." In The Aims of Interpretation. Chicago: University of Chicago Press, 1976.

[3] Husserl, Edmund. Ideas: General Introduction To Pure Phenomenology. Beijing: China Social Sciences Publishing House, 1999.

[4] Inwood, Michael. A Heidegger Dictionary, Oxford: Blackwell Publishers, 1999.

[5] Leech, G. N. A Linguistic Guide to English Poetry. Beijing: Foreign Language Teaching and Research Press, 2001. 